\title{
Rapid Evaluation of Micro-Scale Photovoltaic Solar Energy Systems using Empirical Methods Combined with Deep Learning Neural Networks to Support Systems' Manufacturers
}

\author{
Eisa Almeshaiei ${ }^{1}$, Amin Al-Habaibeh ${ }^{2}$ and Bubaker Shakmak ${ }^{2}$ \\ ${ }^{1}$ Manufacturing Department, College of Technological Studies, The Public Authority for \\ Applied Education and Training, Kuwait \\ ${ }^{2}$ Innovative and Sustainable Built Environment Technologies (iSBET), \\ Nottingham Trent University, Nottingham, UK
}

* Corresponding author: Professor Amin Al-Habaibeh, email: amin.al-habaibeh@ntu.ac.uk

\begin{abstract}
:
Solar energy is becoming one of the most attractive renewable sources. In many cases, due to a wide range of financial or installation limitations, off-grid small scale micro power panels are favoured as modular systems to power lighting in gardens or to be integrated together to power small devices such as mobile phone chargers and distributed smart city facilities and services. Manufacturers and systems' integrators have a wide range of options of micro-scale photo voltaic panels to choose from. This makes the selection of the right panel a challenging task and risky investment. To address this and to help manufacturers, this paper suggests and evaluates a novel approach based on integrating empirical lab-testing with short-term real data and neural networks to assess the performance of micro-scale photovoltaic panels and their suitability for a specific application in specific environment. The paper outlines the combination of lab testing power output under seasonal and hourly conditions during the year combined with environmental and operating conditions such as temperature, dust accumulation and tilt angle performance. Based on the lab results, a short in-situ experimental work is implemented and the performance over the year in the selected location in Kuwait is evaluated using deep learning neural networks. The findings of this approach are compared with simulation and long-term real data. The results show a maximum error of $23 \%$ of the neural network output when compared with the actual data, and a correlation values with previous work within $87.3 \%$ and $91.9 \%$ which indicate that the proposed approach could provide an experimental rapid and accurate assessment of the expected power output. Hence, supporting the rapid decision-making process for manufacturers and reducing investment risks.
\end{abstract}

Key words: Solar energy; system manufacturing; photovoltaic; micro-scale; neural networks; urban environment; smart cities.

\section{Introduction:}

The drive to reduce carbon emission and global pollution has attracted many countries to adopt renewable energy as a future energy strategy. As a result, Kyoto Protocol which 
entered into force in 2005, extending the 1992 United Nations Framework Convention on Climate Change (UNFCCC), had made an obligation on participating countries to reduce greenhouse gas emissions, as indicated by Hopwood (2016) and Balibar (2017). Reducing greenhouse gas emissions is becoming absolutely necessary considering the multitude of scientific papers that have confirmed climate change in many regions of the planet (Seager et al., 2007; Fan and Thomas, 2013; IPCC, 2013; Fu and Feng, 2014; Ávila et al., 2015; Bandoc and Prăvălie, 2015; Prăvălie et al., 2019a).

More recently, in Paris COP21 (Rajgor, 2016), a universal global climate agreement based on individual national contributions has been reached with the main objective is to address global temperature to be well below $2{ }^{\circ} \mathrm{C}$ above pre-industrial levels. It also demands for zero net emissions of greenhouse gases by the second half of this century. According to Prăvălie and Bandoc (2018), solar photovoltaic is more polluting when considering $\mathrm{CO}_{2} / \mathrm{kWh}$ grams that result from the complete solar power production cycle in comparison to wind, CSP, nuclear and hydro energy. However, photovoltaic technology is still one of the most attractive technologies toward reducing carbon emission in comparison to coal, oil and gas due to its relatively low cost and simplicity to the user and the possibility of developing micro-generation and distributed design as well as large scale systems. For many reasons of technical, financial, safety, installation or legal nature, the off-the-grid independent micro scale systems are normally attractive for many applications. This stand-alone technology has its own appetite by systems' integrators and manufacturers due to the modular lower investment requirements and simpler installation procedures.

Researchers have shown that adaptation of solar energy is linked to household income and wealth (Guta, 2018), hence in many rural areas around the world, micro-scale technology is ideal for installation due to its simplicity and stand-alone application. Solar photovoltaic technology is capable of fitting a wide range of requirements with high levels of scalability from milli-watt to almost giga-watt range. However due to many geographical and climate factors, the amount of solar energy production varies in its magnitude and intensity (IEA, 2018). Photovoltaic solar energy technologies have been investigated for a significant periodof-time and research is now moving to a wide range of installation configurations such as over canals, reservoirs, parking spaces, driveways, roads and possibly on highways (Nasir, Hughes and Calautit, 2017).

The most common photovoltaic technologies can be categorised as the crystalline family and the thin film family. The crystalline family includes Crystalline Silicon (cSi), Monocrystalline Crystal Silicon and Polycrystalline Crystal Silicon which represent about 85\% of the global market with module efficiency from $15 \%$. The thin film market available technologies are subdivided into three main sub-families: Amorphous (a-Si) and Micromorph silicon (a-Si/lc-Si), Cadmium-Telluride (CdTe), Copper-Indium-Diselenide (CIS) and Copper-Indium-Gallium-Diselenide (CIGS). However, thin film photovoltaic modules have about $15 \%$ of world photovoltaic market with an efficiency starting from 10\% (Miao et al., 2018).

To estimate the expected output from solar panels, several mathematical models and approaches have been investigated and compared in literature. The approaches are normally mathematical-based, such as the ones presented by Pindado and Cubas (2017), Xu et al. (2018) and Prăvălie et al. (2019b), where performance of solar panels is calculated via solar irradiation at specific location and efficiency of the photovoltaic system. This is a low cost and rapid approach to estimate the cost and performance. Other techniques use experimental 
models of 1:1 scale systems of lab or outdoor environment, such as Klucher (1979), AslSoleimani et al. (2001), Sharaf-Eldin et al. (2016), Maghami et al. (2016) and Elibol et al. (2017). Such systems are useful in calculating many parameters of the actual components and estimating the actual energy generated in a specific location. Others use a combination of both approaches such as Abdelghani-Idrissi et al. (2018) and Jamil and Bellos (2019), where mathematical modelling and scientific experiment on 1:1 scale system is developed. However, the experimental studies not only could be expensive and complex, but will need significant time (at least one year) to collect the data needed to understand the performance. Even with such approach, the results will be varied due to weather conditions and other environmental factors. Hence most of the available databases use an average reading over several years such as NASA Surface Meteorology and Solar Energy (NASA, 2018).

Methodologies for the estimation of the hourly global solar radiation have been well investigated by many researchers including Davies and McKay (1989), Gueymard (1993) and Kaplanis (2006). The main aim is to estimate solar radiation and daylight illuminance to evaluate expected hourly power output with the necessary invertors and control systems. A recent paper (Li and Lou, 2018) has presented an extensive review of solar irradiance and daylight illuminance modelling and sky classification. In Lou et al. (2017), the 15 standards adopted by International Commission of Illuminance (CIE) are discussed and a methodology for Sky classification by accessible climatic indices are presented. The approach has successfully identified $83.2 \%$ of partly cloudy and clear skies scenarios, and further $62.7 \%$ of the 15 CIE Standard Skies for Hong Kong.

Other factors such as dust accumulation and temperature of the panels could significantly change the performance. Gholami et al.(2018) noticed that dust accumulation caused the reduction of power produced by photovoltaics. This clearly indicates that weather conditions and climate change have influence on the efficiency of photovoltaics. They elaborated that a drop of $25 \%$ of transmission coefficient of photovoltaic power is lost due to the effect of dust gathering over solar cells. In addition, Touati et al. (2017) went further to test the effect of climate on generating power using photovoltaic cells. A power production efficiency comparison is made between a Mono-Crystalline and an Amorphous cell in relation to dust accumulation. It had concluded that an Amorphous cell is out preform a Mono-Crystalline cell in power production under this specific weather condition.

The efficiency of solar cells in energy production is a major area for researchers. Many experimentations had endeavoured to evaluate the performance for photovoltaic panels under a variety of influencing parameters and presented emphasis on the photovoltaic optical properties (Dupeyrat et al., 2011). The techniques suggested are either to experimentally install and monitor photovoltaic panels over longer periods of times or using simulation software based on general assumptions and theoretical analysis. Other researchers such as Fthenakis (2004) and Díaz (2013) have gone further to address the issue of photovoltaic manufacturing and materials and its effect on life cycle performance. Furthermore, Cañete et al. (2014) have investigated different photovoltaic equipment performance on an open-air environment. In addition, Elbreki et al. (2016) have used the same measures to test photovoltaic performance, while Lude et al. (2015) have studied a variety of photovoltaic types technologies which has been utilised in Kuwait Energy Park to investigate power production efficiency to find a suitable one which can overcome Kuwait climate circumstances for a wider installation. In relation to renewable energy, Prăvălie et al. (2019b) have presented spatial assessment of solar energy potential at global scale including Kuwait 
and the Arabian Peninsula, where in Kuwait the annual global horizontal irradiation (GHI) ranges between 2035.9 and $2221.8 \mathrm{kWh} / \mathrm{m}^{2}$.

In addition to solar potential in the region, there are other renewable resources that could be harnessed, such as wind. The wind power density, as indicated by Bandoc et al. (2018), is about 300 to $400 \mathrm{~W} / \mathrm{m}^{2}$, which is an average value in comparison to other areas around the world. Both wind and solar energy have a huge potential in that region, however, solar photovoltaic technology seems to be an easier to install and use.

In general, each approach has its own drawback. The experimental approach is expensive and takes significant time to get the necessary data. Even with this, environmental conditions could change year upon year (e.g. temperature levels, clouds, rain, dust, pollution, etc.). The mathematical modelling and computer simulation approach is a low cost approach and takes shorter period of time to get the results. However, a wide range of assumptions will be needed. There are standard methods to test solar panels for heating and actinic effects. Independent third party testing and certification is normally performed and when combined with manufacturer's quality management system, this should provide assurance to systems manufacturers and users. Although databases such as the Photovoltaic Geographical Information System of the European Commission (PVGIS, 2018) can be used to estimate the output of systems, what we have found that systems manufacturers would prefer to do their own testing to evaluate the specific technology they are using. The drive to reduce the cost and rapidly response to market, makes the systems manufacturers and integrators keen to rapidly test, on case by case basis, most products and designs. When a system manufacturer is faced by a decision to choose from several panels on performance basis, the requirements normally could go beyond the standard certification in order to optimise the design to a specific location. Hence, this paper will address such scenario using a case study from Kuwait, which is characterised by hot weather. Currently, many micro-scale and off-grid products are being sold for a wide range of applications in Middle East and Africa, and there is a demand to optimise their own design and manufacturing.

Based on the above discussion, this paper combines the strengths of the two approaches, namely experimental and simulation, in a novel and new approach which utilises neural networks for self-learning. The lab testing utilises empirical work on small scale models using an architectural test-rig, named the Heliodon, which is a commonly used to evaluate the light angle based on the time of the day and the month of the year at any latitude on earth. Then the suggested methodology could be calibrated using real values of solar power levels and temperatures with support from neural networks to provide potentially more accurate prediction of performance.

\section{Methodology and Experimental Work}

\subsection{Methodology}

In this paper, a manufacturer is faced with the problem of selecting one of two suitable micro-scale solar panels for a product: a polycrystalline and Amorphous photovoltaic panels as shown in Figure 1. There is a need to evaluate which type could be more efficient in order to be integrated in hot countries and to produce a better power per $\mathrm{m}^{2}$ for their device given that both meets the minimum specifications needed and have comparable cost per square meter. 


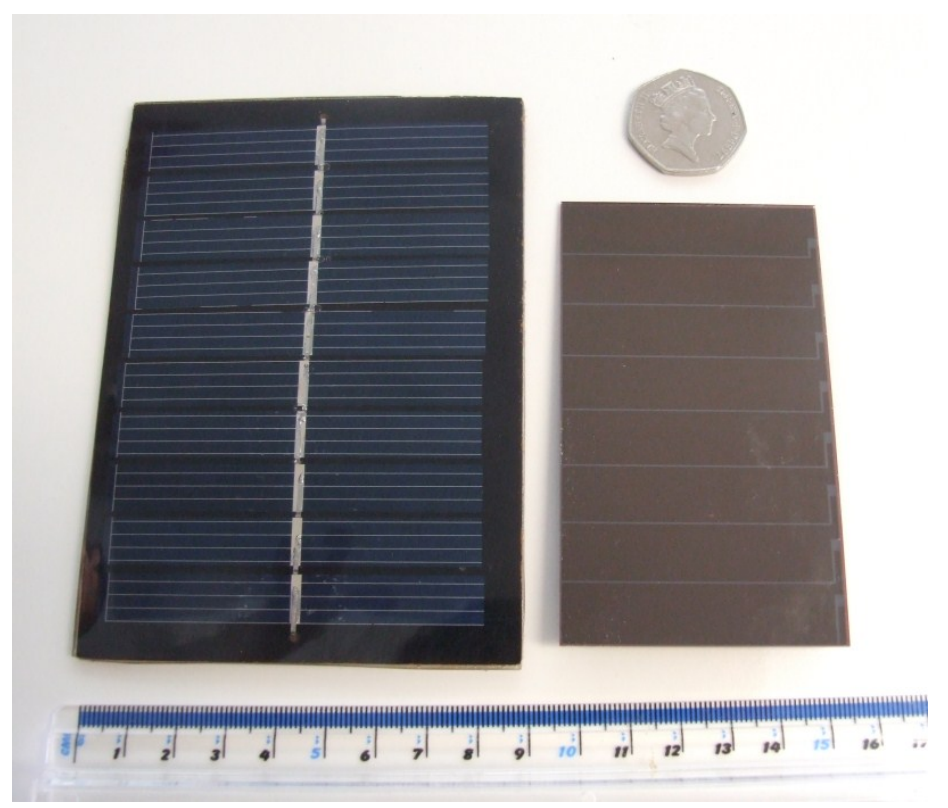

Figure 1: The solar panels used for the test, polycrystalline (left) and Amorphous (right).
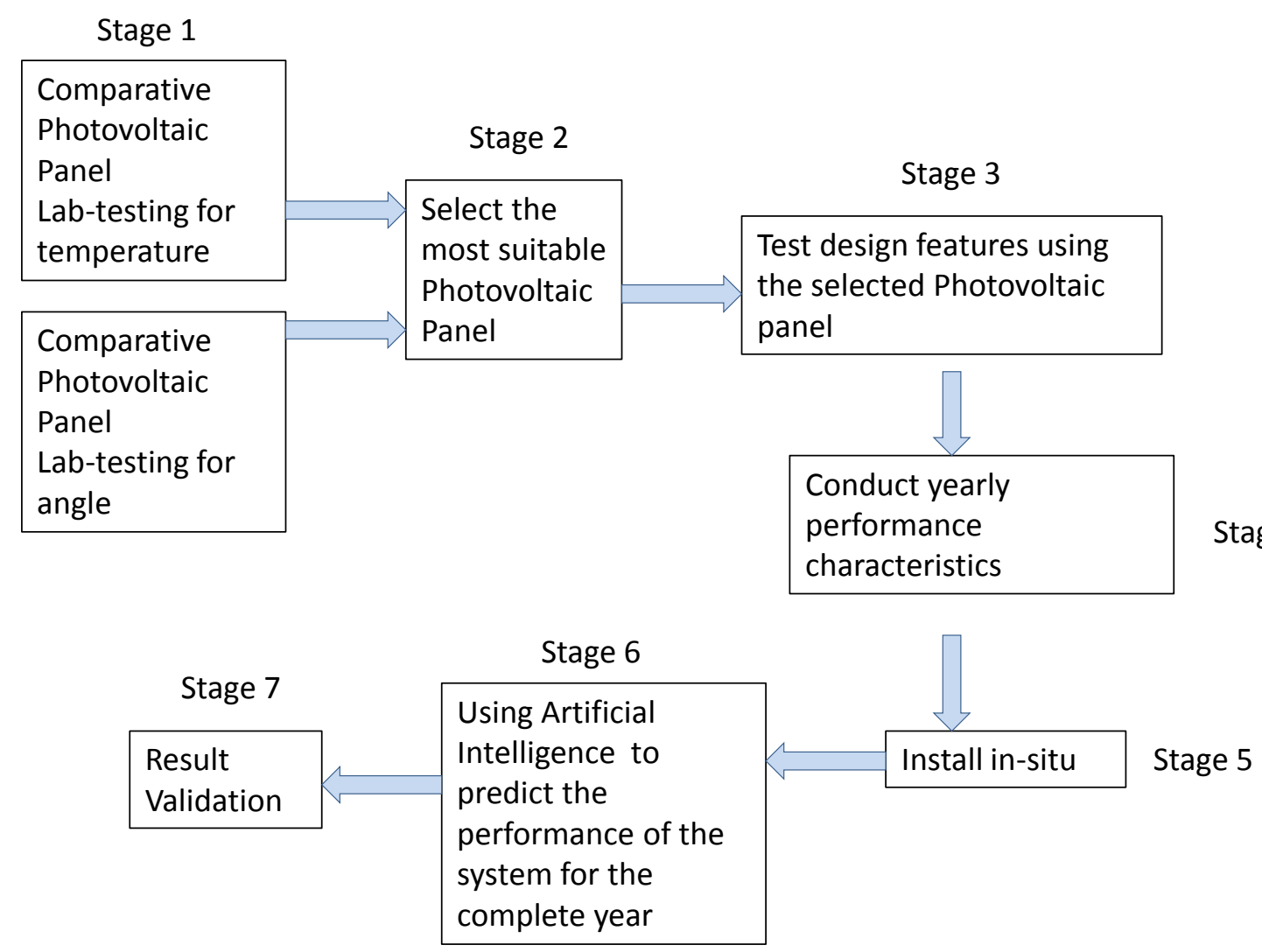

Figure 2: The Methodology implemented in this research work.

Figure 2 presents the methodology implemented in this research work. The lab testing involves the use of a standard Heliodon test-rig, see Figure 3, which is normally used by architects to evaluate architectural models by simulating the year's months at different times of the day at different latitudes. 


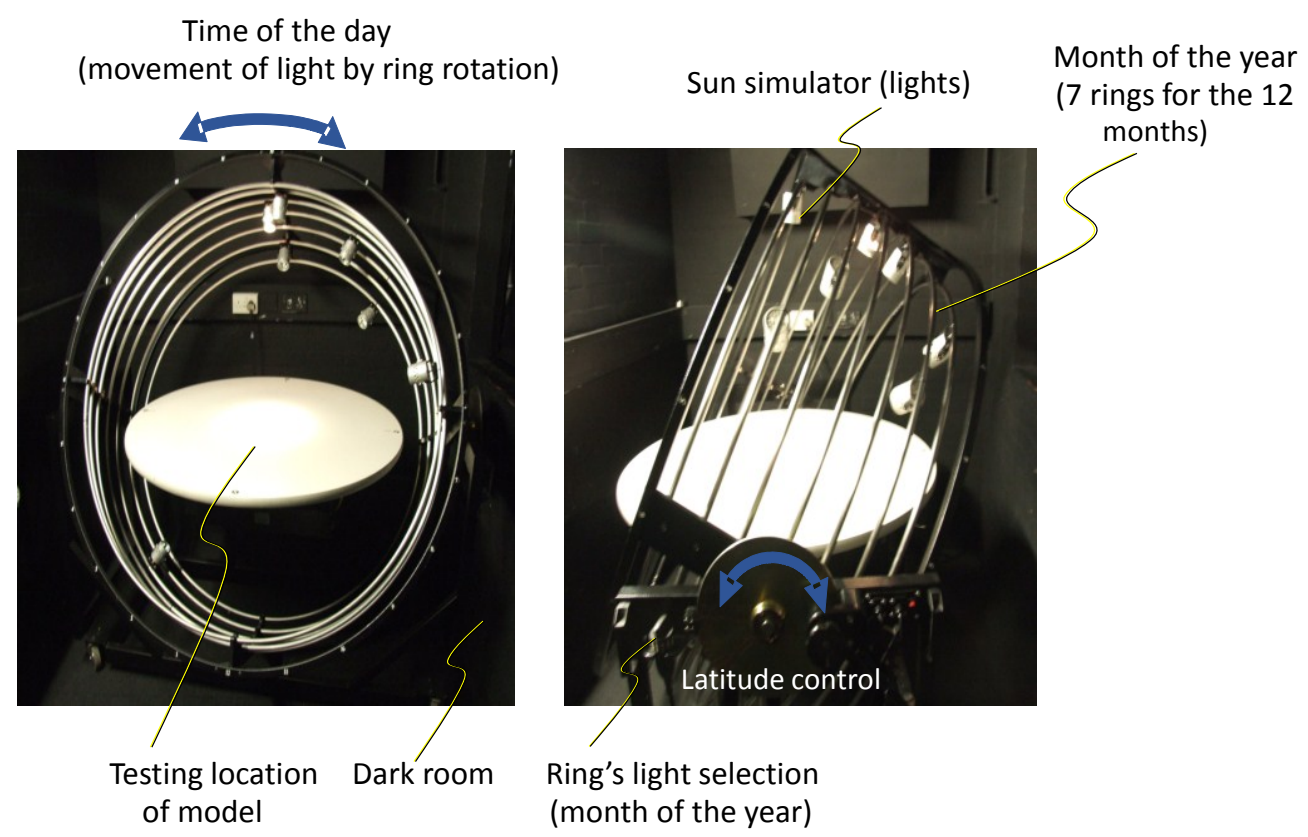

Figure 3: The innovative approach uses the Heliodon test rig.

The Heliodon apparatus Figure 3 contains around table and seven cylindrical bars represents the 12 months of the year. A spot light hocked onto each cylindrical bar that used as the sun during the day. All cylindrical bars are attached into a big circle with time marked as hourly basis from dawn to dusk for a particular month of the year. The Heliodon apparatus is designed originally for use in architectural projects, to evaluate on small scale the influence of the light and shadow on building design. By rotating a main frame which the monthssolar-paths (rings) are connected to, the latitude of the location can be altered. The main frame is attached to a dial which shows the degrees of latitude for variety of locations on the globe. The selection of any month will change the angle of the solar radiation on the panel. Rotating the rings that are related to each month will simulate the time from sunrise to sunset. The temperature of the panels is controlled via electric heaters to study also the effect of the temperature on the efficiency.

Stage 1 of the methodology, see Figure 2, involves a comparative study between the performance of the selected photovoltaic panels of the product, where the temperature and angles of the panels will change to comparably examine which one performs better under different temperature ranges and angles. The selected panel (Stage 2) will then be used in Stage 3 to evaluate the design features of the product. In this case, the performance of three tilt angles will be assessed: vertical $\left(90^{\circ}\right)$, horizontal angle $\left(0^{\circ}\right)$ and $50^{\circ}$ angle. The three angles are chosen based on a design selection process to manufacture and deploy a product in Kuwait's environment. Such features will be evaluated in relation to power output and sand accumulation in sandy or dusty environment. Stage 4 will assess the performance of the panel for the three selected tilt angles with fixed south facing azimuth angle. Following the assessment of the yearly power output per hour and month (Stage 4), Stage 5 involves testing the panel in situ to calibrate the lab data using deep learning neural networks (Stage 6). Stage 7 involves validation of the data by comparing the results with other known data for validation. 


\subsection{Experimental work}

For this case study the micro-scale panels will be tested in Kuwait, Table 1 summarises the conducted tests with approximate location of $30^{\circ} \mathrm{N} ; 47.7^{\circ} \mathrm{E}$. The experimental work is first performed to compare between Amorphous and Polycrystalline panels, see Figure 4. This is simply to investigate if the results of the system are comparable to the findings of any specifications and other researchers' work. The first test is to compare the power of the two types with changing the tilt angle (slope). The second general test is to check which type is less or more sensitive to temperature. The two tests are presented in Table 1 (tests 1 and 2). Based on the results, as will be explained in the following sections, the Amorphous type was selected for the rest of the work. Following the selection of the Amorphous panel, the manufacturers had three options of design for tilt angle of 90 degrees, 0 degrees and 50 degrees. This was based on three design ideas that will be tested for future manufacturing and deployment. For this, a test-rig is used as shown in Figure 4 to evaluate the performance.

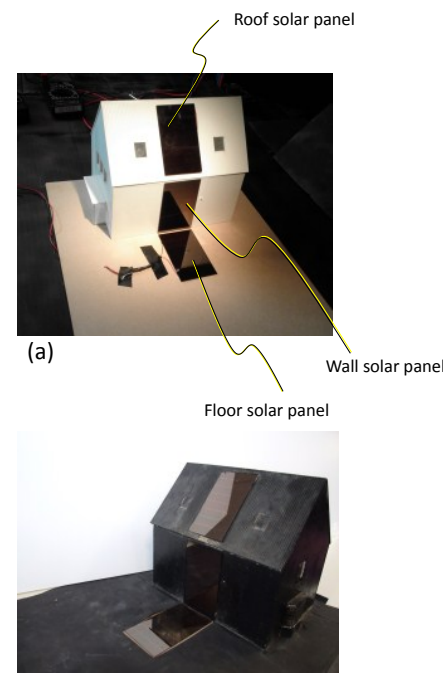

(b)

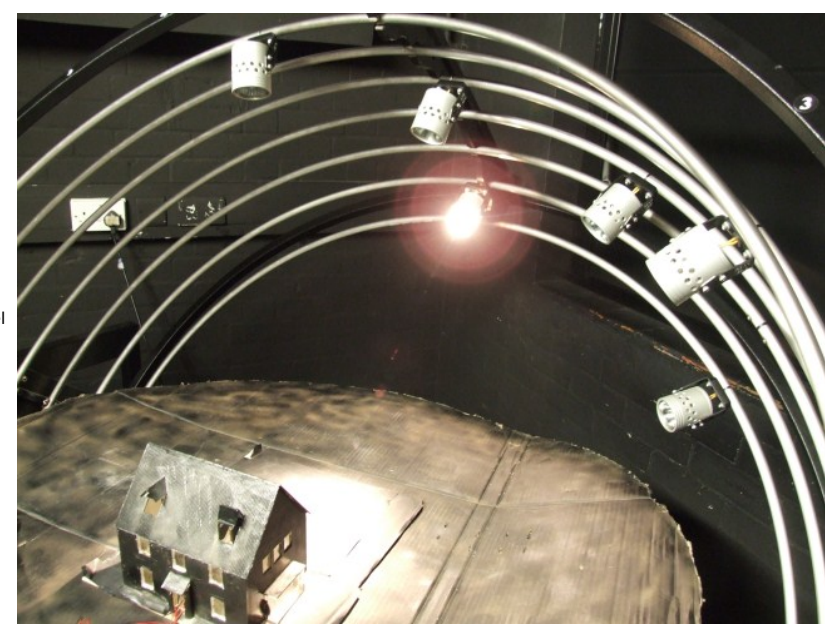

(c)

Figure 4: The small scale model to the test the panels (a), the model painted matt black (b) and the experimental work with the building model in situ (c).

Kuwait parameters (latitude of 30 degrees) are used on the test rig and sand from a real sand storm in Kuwait is used to spray the three panels in the three configurations (pitched roof $50^{\circ}$, wall $90^{\circ}$ and floor $0^{\circ}$ ) to see the sand accumulation on the three angles. The sand storm test is presented in test 3 of Table 1. Following this, south facing (Azimuth $=0$ ) installation is tested to see the difference in performance in the lab test. 
Table 1: The experimental work conducted.

\begin{tabular}{|c|c|c|}
\hline $\begin{array}{l}\text { Test } \\
\text { No }\end{array}$ & Description & Aim \\
\hline 1 & $\begin{array}{l}\text { Lab testing of tilt angle and power } \\
\text { out of Amorphous and } \\
\text { Polycrystalline panels. }\end{array}$ & $\begin{array}{l}\text { Testing the sensitivity of the power output to } \\
\text { the tilt angle, hence identifying the most } \\
\text { suitable of the two types. }\end{array}$ \\
\hline 2 & $\begin{array}{l}\text { Lab testing of the effect of } \\
\text { temperature on Amorphous and } \\
\text { Polycrystalline panels. }\end{array}$ & $\begin{array}{l}\text { Testing the effect of temperature variation on } \\
\text { the two most common types of photovoltaic } \\
\text { panels. }\end{array}$ \\
\hline 3 & $\begin{array}{l}\text { Lab testing of sand storm effects } \\
\text { on three (tilt angles). }\end{array}$ & $\begin{array}{l}\text { Identifying the type of installation and the } \\
\text { effect of the tilt angle on sand build-up. }\end{array}$ \\
\hline 4 & $\begin{array}{l}\text { Lab testing of solar energy } \\
\text { patterns at latitude of } 30 \text { degrees } \\
\text { (Kuwait). }\end{array}$ & $\begin{array}{l}\text { Studying the solar patterns at Latitude of } 30 \\
\text { degrees (Kuwait), south facing. }\end{array}$ \\
\hline 5 & $\begin{array}{l}\text { In situ real testing in Kuwait Solar } \\
\text { energy patterns at latitude of } 30 \\
\text { degrees (Kuwait). }\end{array}$ & $\begin{array}{l}\text { Studying the performance in situ to calibrate } \\
\text { the system. }\end{array}$ \\
\hline
\end{tabular}

The three photovoltaic panels in Figure 4 for the three configurations are connected to a shunt resistor that produces the maximum power at room temperature and kept fixed during the experiments to simulate a fixed load on the system. A volt-meter was connected to the solar panels, and in this case the produced power can be calculated using:

$$
\mathrm{p}=\frac{\mathrm{V}^{2}}{\mathrm{R}}
$$

where $\mathrm{p}$ is the power $(\mathrm{W}), \mathrm{V}$ is the measured voltage $(\mathrm{v})$ and $\mathrm{R}$ is the fixed resistance $(\Omega)$. Also temperature sensors (thermocouples) are used to measure the temperature at the back of the panels. Electric heaters are used to heat the panels to a specific uniform temperature.

Based in which, the energy produced can be calculated by:

$$
\mathrm{E}=\mathrm{Pt}
$$

where $\mathrm{E}$ is the energy in $\mathrm{kWh}, \mathrm{P}$ is the power in $\mathrm{kW}$ and $\mathrm{t}$ is time in hours $(\mathrm{h})$.

Hence from (1) and (2), $\quad \mathrm{E}=\frac{\mathrm{V}^{2}}{10^{3} \mathrm{R}} \mathrm{t}$.

Assuming the solar panel area is $A$ in $\mathrm{m}^{2}$, hence the energy per $\mathrm{m}^{2}$ (q ) will be:

$$
\mathrm{q}=\frac{\mathrm{V}^{2}}{10^{3} \mathrm{RA}}
$$

where $\mathrm{q}$ is in $\mathrm{kWh} / \mathrm{m}^{2}$. 


\subsection{Deep Learning Neural Networks}

To predict the behaviour of the solar panels in situ, a supervised Back-Propagation Neural Network is used for deep learning for this research work. This has the advantage of learning from experience and develop non-linear relationship between input variables. During supervised learning the input stimulus is applied which results in an output response, which is compared with the desired output (i.e. the target response). If the actual response differs from the target response, the neural network generates an error value. The error $\mathrm{E}$ is then used to calculate the adjustment that should be made to the networks synaptic weights, so that the actual output matches the target output. For the selected neural network in Matlab (Amin et al., 2008) , Levenberg-Marquardt algorithm (Mathworks, 2019) is used as one of the most common algorithms is supervised neural networks.

$$
\mathrm{E}=\frac{1}{2} \sum_{\mathrm{i}}\left(\mathrm{t}_{\mathrm{i}}-\mathrm{y}_{\mathrm{i}}\right)^{2}
$$

where $t_{i}$ desired or target response for ith unit and $y_{i}$ actually produced response for ith unit.

\section{Results}

\subsection{Tilt Angle (slope) and Power/Voltage}

From Figure 5 it can be observed that the Amorphous panels are less sensitive to the tilt angle in comparison to the polycrystalline. The power in general is less for the same light intensity and the power drops much faster for the polycrystalline, but more gradual (lower slope) for the Amorphous. From Figure 5, it can be concluded that the Amorphous panel is outperforming the polycrystalline and hence the Amorphous will be used for the further tests in this paper.
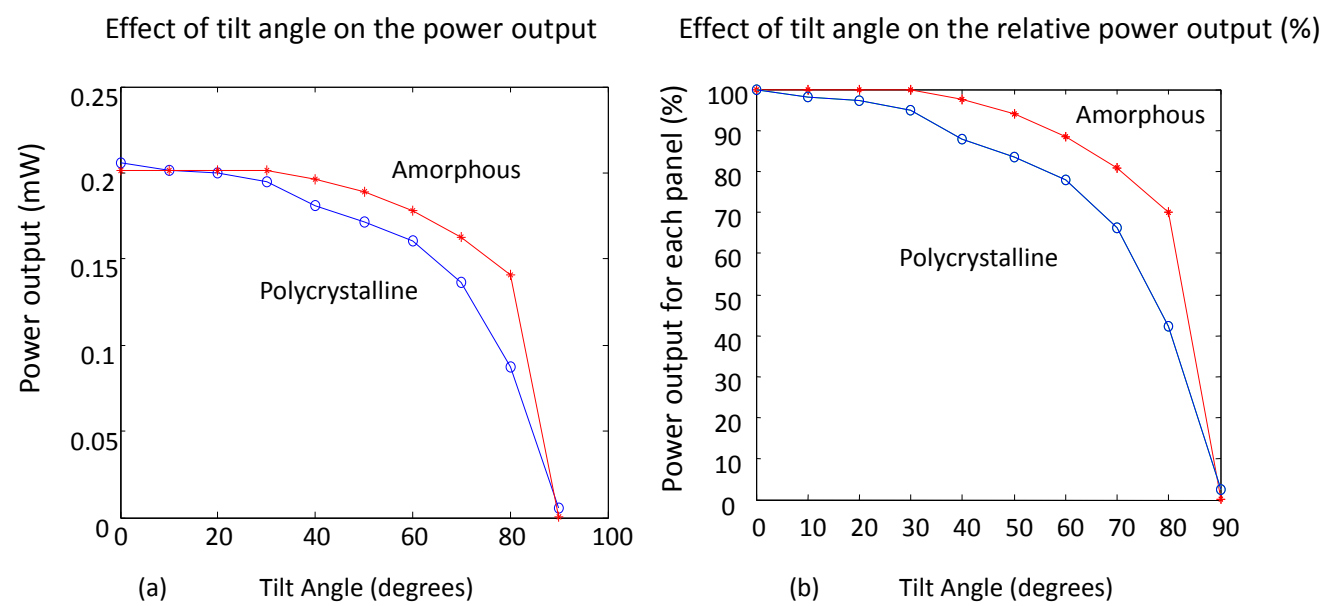

Figure 5: The effect of tilt angle (slope) on the power output in $\mathrm{mW}$ (a) and relative power (5) output for Amorphous and Polycrystalline panels (b). 


\subsection{Temperature and Power output}

Figure 6 presents the results of the effect of temperature on the Amorphous and Polycrystalline panels. It can be observed that the Amorphous solar panel (thin film) is less sensitive to temperature and is much better performing than the polycrystalline. The Amorphous panel power has dropped 33\% between 25 degree to 70 degrees, while the Polycrystalline has dropped $57 \%$ for the same range of temperatures. In this case, the Amorphous panel outperforms the polycrystalline by about $30 \%$ of relative power output. The difference in the heating and cooling at the same temperature shows more diversion at the same temperature for the Polycrystalline panel in comparison to the Amorphous panel. Figure 6-a presents the measured power and Figure 6-b presented the normalised power for each solar panel separately.
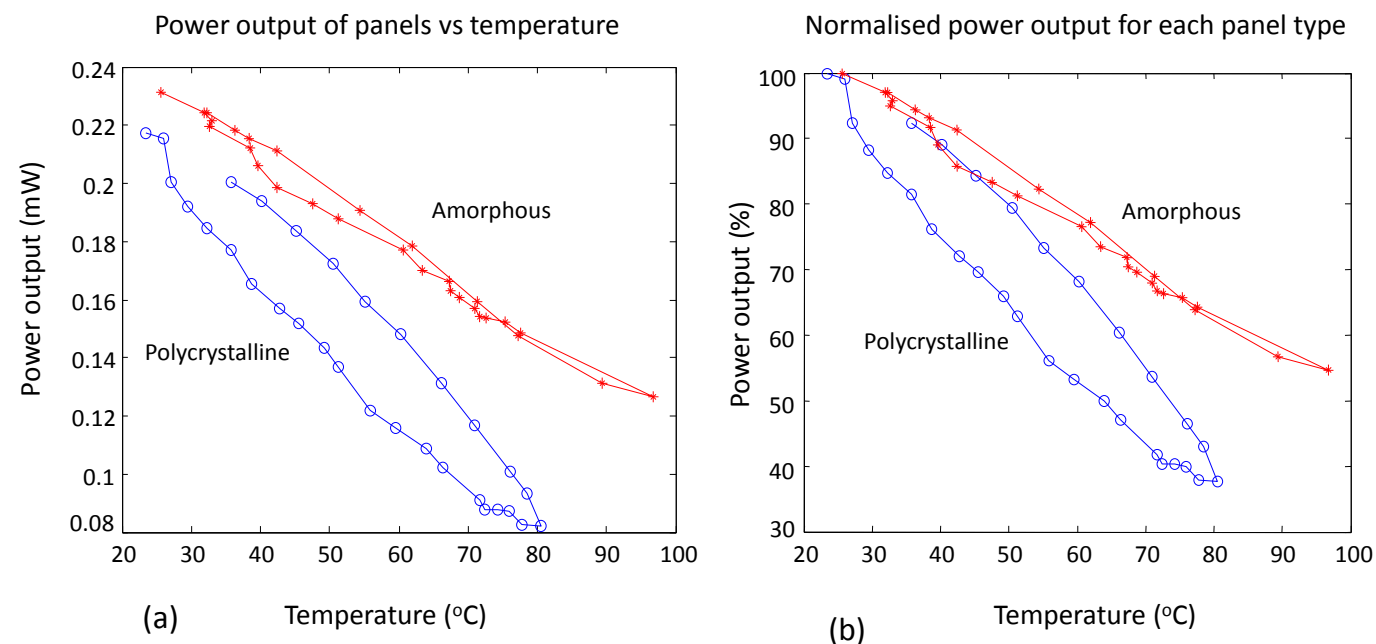

Figure 6: The effect of temperature on Amorphous and Polycrystalline solar panels.

\subsection{Sand storm effects on three tilt (slope) angles}

Figure 7 presents the effect of the sand storm simulation in a lab environment on the power output for the pitched surface, wall and floor. The Amorphous panels have been selected as the benchmark to conduct the rest of the tests due to its comparative high performance. The accumulation of desert sand or dust was monitored during the system testing in Kuwait as well as using simulated lab test with sand and dust brought specially from Kuwait and sprayed in an enclosed environment to see the accumulation phenomena. In relation to sand storm and the effect on the panels, as expected, the horizontal or floor panel (slope of $0^{\circ}$ ) has accumulated the maximum sand which reduces the energy production significantly (Figure 7-c). The vertical wall panel (slope of $90^{\circ}$ ) shows the least difference (Figure 7-b). It has been found that the floor is the most sensitive to a 
stand storm. The pitched roof (slope $=50^{\circ}$ ) is also very sensitive except from one angle during June, which could be related to the reflective nature of the sand particles at specific angle. But in general, walls solar panels are much more stable for sandy weather (with no cleaning).

(a)

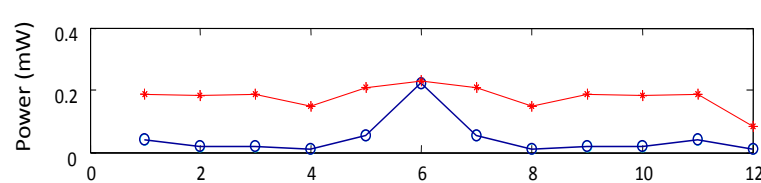

Roof

(b)

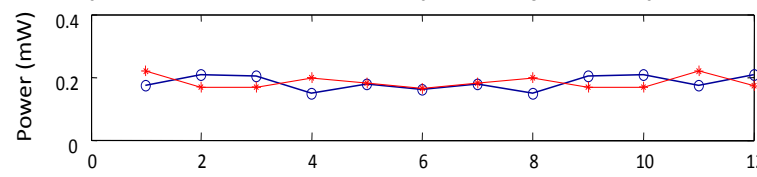

(c)

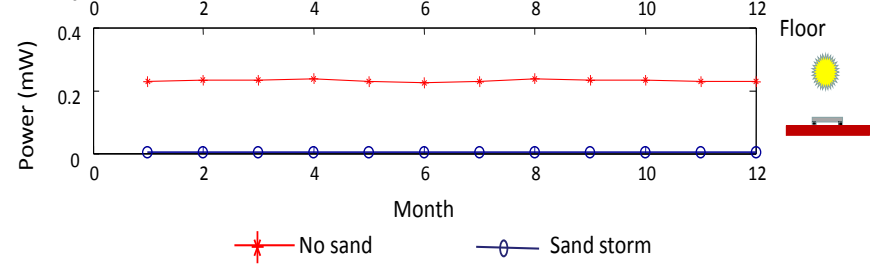

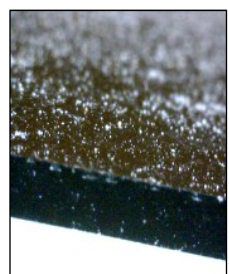

Sand particles on

the surface

Figure 7: The effect of sand storm on Amorphous solar panels output.

\subsection{Solar energy patterns at latitude of 30 degrees (Kuwait) -South facing}

Figure 8 presents the solar output from locations of latitude of 30 degrees (Kuwait). It has been found that the floor panels are outperforming the walls and pitched roof. The pitched roof in June has relatively reasonable output when compared with December. However, the wall and floor panels are more sensitive to the shadow during June, while the pitched roof produces the maximum output in June despite the fact it is not an optimised angle. According to NASA (2018), the optimised angle theoretically should be about $55^{\circ}$ in winter but in summer should be much less (about $15^{\circ}$ ).

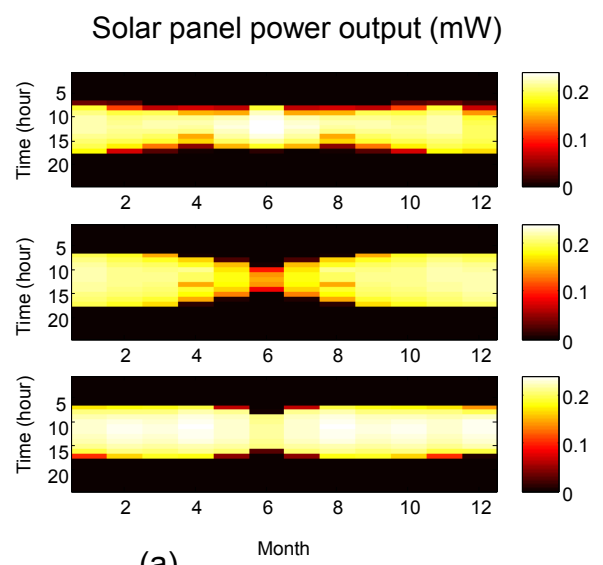

(a)

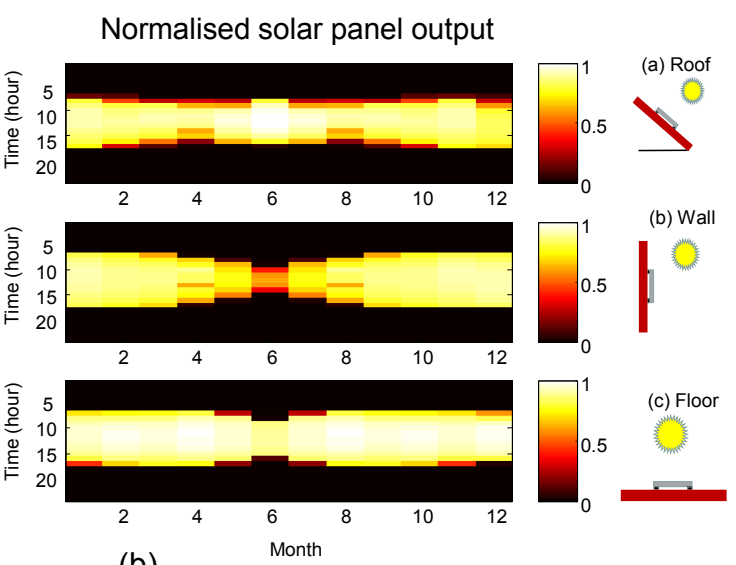

(b) 
Figure 8: Solar output at latitude of 30 degrees (Kuwait) -south facing, where power is in $\mathrm{mW}$ (a) and normalised (b).

Figure 9 presents a comparison between December (winter) and June (summer). The results for the pitched roof clearly show that in summer the power output has higher values, but in December the energy at 50 degrees seems to be better suited for winter and hence the power just before sunset seems to be higher than in summer. The wall provides better performance in winter than summer mainly because the sun is more facing the wall and the shadow is reduced. Figure 10 presents the total energy produced in a year using the model, the floor had the maximum output followed by the wall and the pitched roof respectively for the given angles. Figure 10-a presents the potential annual energy output for the three slope angles. It is clear that floor panels are much better than wall or angled panels. However, due to the sand test, the 50 degrees is selected due to its performance. Based on the Photovoltaic Geographical Information System of the European Commission (PVGIS, 2018), the average hourly data can be obtained for Kuwait. Comparing the south facing data for the three configurations with the data from the website, the correlation coefficient is documented in Figure10-b. Note that the $50^{\circ}$ has the highest correlation coefficient when compared with the real data. Based on the above discussion, the manufacturers have selected the 50 degree configuration for the final product design as a compromise.
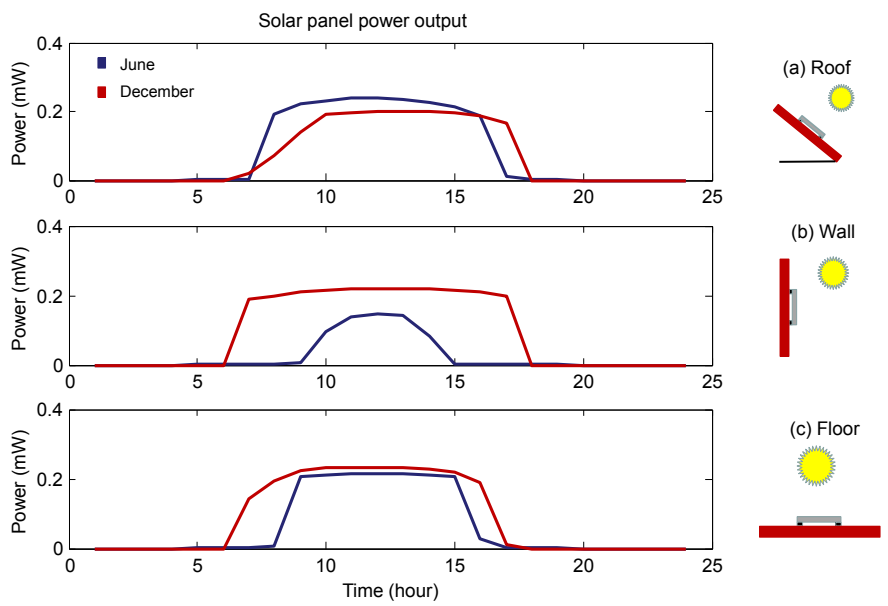

Figure 9: Solar output at latitude of 30 degrees (Kuwait) for months of December (winter) and June (summer) in $\mathrm{mW}$. 


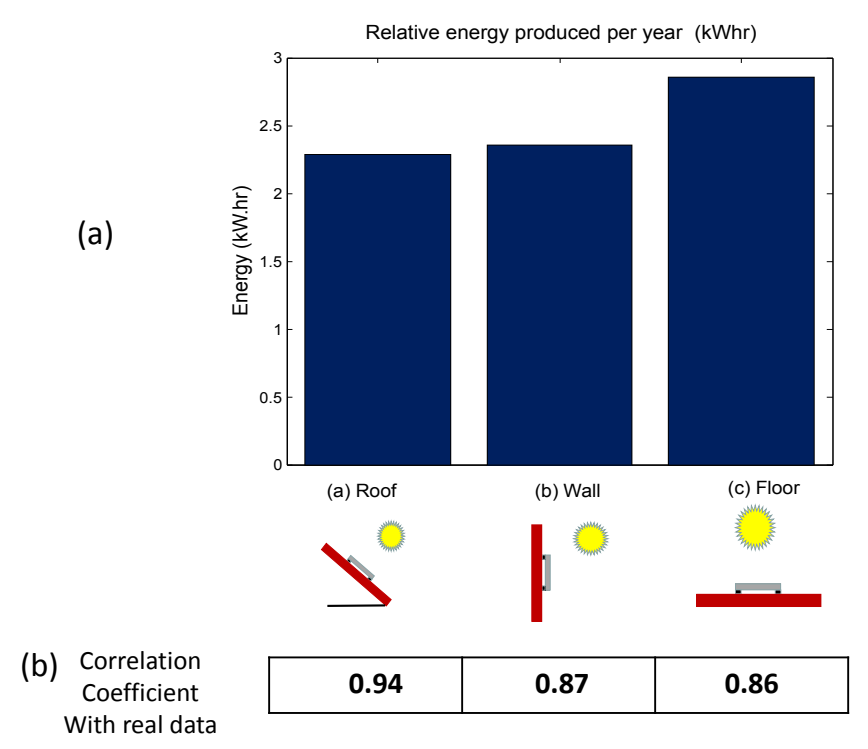

Figure 10: Comparative results of annual potential energy production (Kuwait scenario) (a) and the correlation coefficient between hourly data from The European Commission website (Photovoltaic Geographical Information System (PVGIS), European Commission, 2018) and the experimental lab work of Kuwait (latitude 30 degrees) (b).

The results show high correlation between the suggested system and the real data obtained by the Photovoltaic Geographical Information System of the European Commision (PVGIS, 2018). This is a clear indication of the benefits of the suggested technology. However, one of the limitations of the apparatus is the lack of control on the light intensity to better simulate the angle and the sun irradiation at different times of the year. When studying solar panels in real situations, the cost is normally very expensive and the results might not be conclusive in anyway due to the variation in weather, dust and other factors. However, a short-term in-situ testing could provide the needed information to fully evaluate the suggested approach where this will be described in the next sections.

\subsection{Results of experimental work in Kuwait}

The same model has been installed in-situ in Kuwait, see Figure 11, for testing in July of 2018. Figure 11-a presents the model at location, Figure 11-b presents the power output in $(\mathrm{mW})$ during one of the days in July as hourly average and Figure 11-c presents the hourly average temperature. Data acquisition systems are used to log the data every 10 minutes to capture the variation in performance in voltage and temperature. Based on the average hourly output for one typical day in July, a neural network is implemented to predict the average hourly for every month for the whole year to calibrate the lab tests, as in Figure 8. The neural network, Figure 12, has used the July lab data for training while July in-situ data as a target for the neural networks. The neural networks had also the relevant variables, namely the hour and month of each input, the tilt angle $\left({ }^{\circ}\right)$ of the panel, environmental temperature, efficiency of the photovoltaic panel (\%) at the associated temperature and 
finally the solar radiation at location calculated per as hourly average from The European Commission website (PVGIS, 2018).

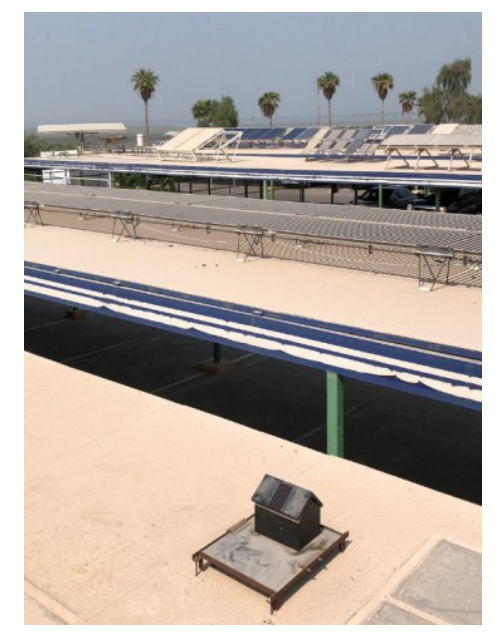

(a)
Hourly average power and temperature levels during one day on 30 July 2018

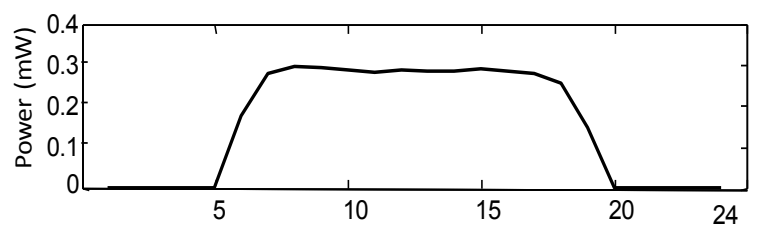

(b)

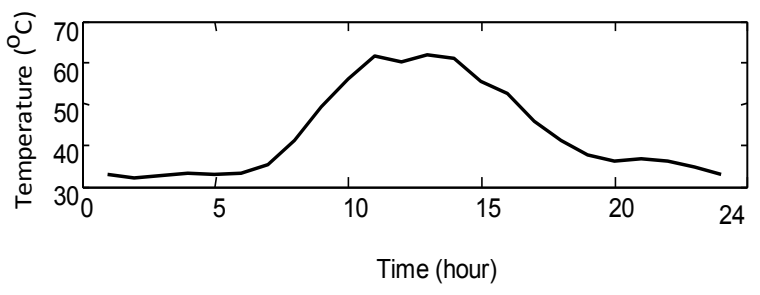

(c)

Figure 11: The experimental work that we performed in Kuwait (a) and the solar panel output and temperature (b).

\subsection{The Neural Networks Implementation}

For the supervised neural network used for deep learning, Levenberg-Marquardt algorithm is implemented using Matlab with the 'trainlm' function. The neural network has 7 inputs as outlines in Figure 12. The neural network has a learning rate of $1 \times 10^{-7}$, a momentum of 1 $\times 10^{10}$, a target error of 0.001 , transfer functions of sigmoid for the hidden layer with 10 hidden nodes and linear function for the output layer, see Figure 12. 


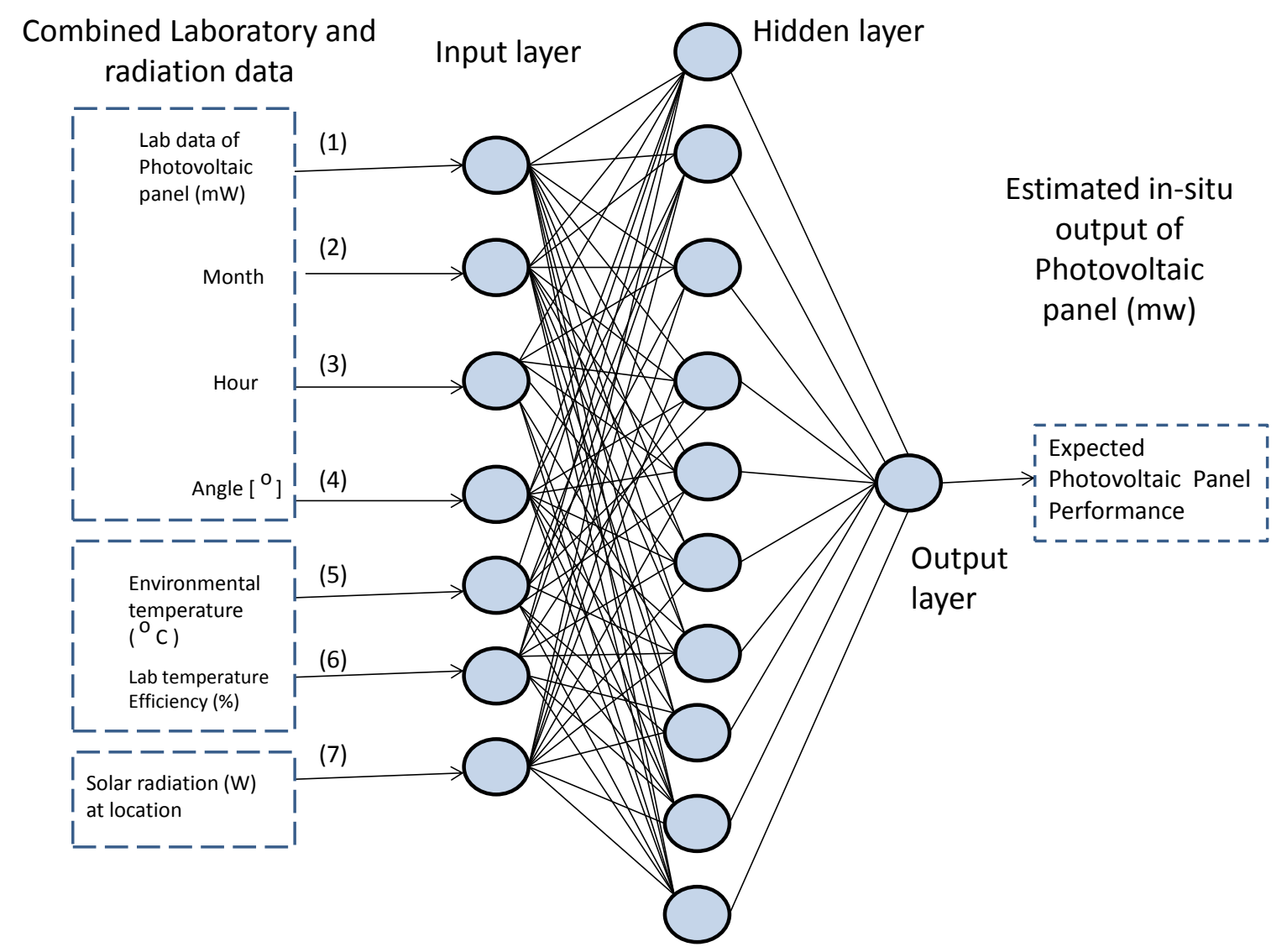

Figure 12: The function fitting neural network implemented in this research work and the input types to calibrate lab data to predict in-situ performance.

Following the training for July lab data, the system is tested using the lab data From January to December with hourly average (as in Figure 8) but with other associated inputs to the neural networks as in Figure 12. The results are presented in Figure 13, with maximum prediction power error between $0.46 \%$ and $23 \%$ for months August 2018 to January 2019, where the prediction is compared with real data, as the system was kept in operation to compare results. Figure 14 presents the predicted neural network output for the 12 months based on the hourly average power output $(\mathrm{mW})$. 
Post-Print Version: Eisa Almeshaiei, Amin Al-Habaibeh, Bubaker Shakmak, Rapid evaluation of micro-scale photovoltaic solar energy systems using empirical methods combined with deep learning neural networks to support systems' manufacturers, Journal of Cleaner Production, 2019, 118788, ISSN 0959-6526, https://doi.org/10.1016/j.jclepro.2019.118788. (http://www.sciencedirect.com/science/article/pii/S0959652619336583)
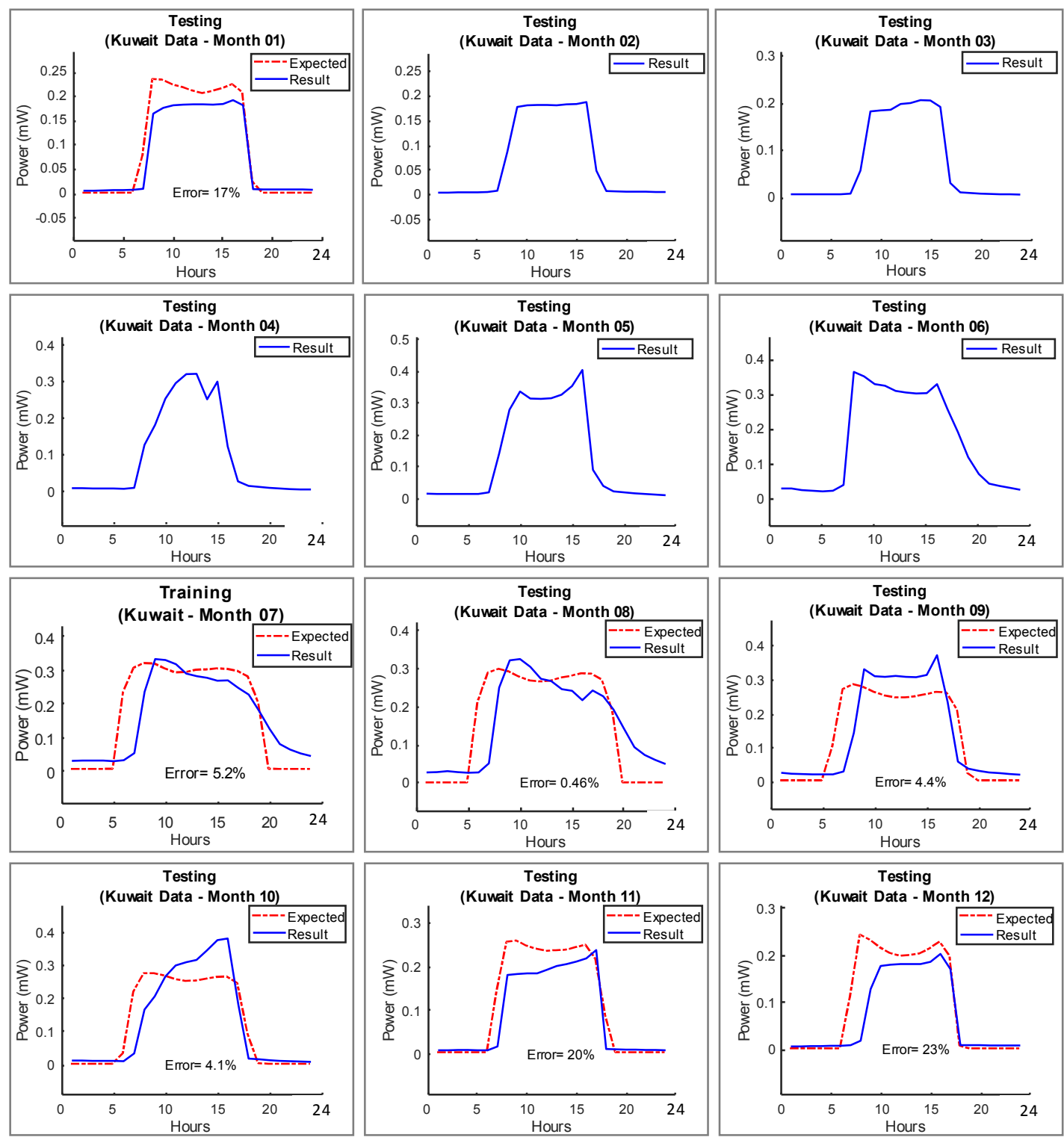

Figure 13: July data is used for training the neural networks and the lab-data and other associated data is used to test the neural networks. 


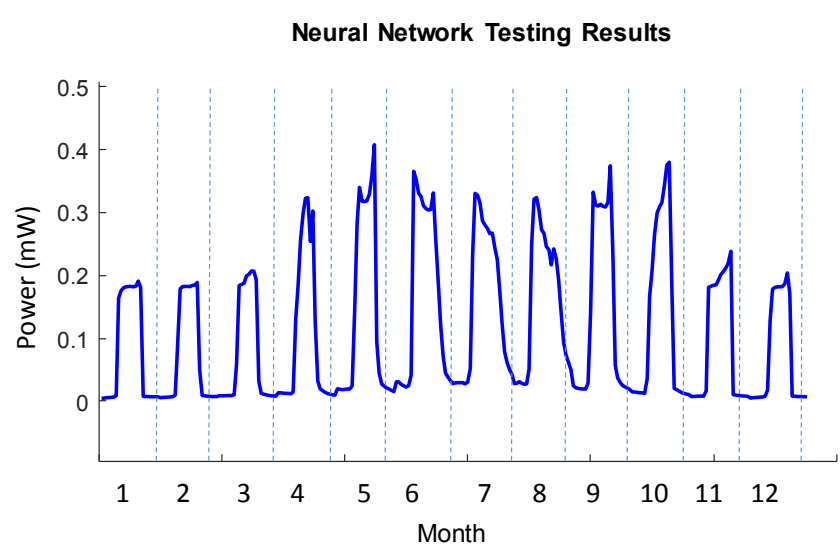

Figure 14: The predicated output of the neural networks during the year as average daily performance.

To further validate the neural network output for the months that were not covered in-situ, the results of the neural network are comapred in terms of correlation with other emprical research (Bou-Rabee and Sulaiman, 2015) for the whole year and simulation (Ali et al., 2017) in Kuwait, as shown in Figure 15. The results show correlation figures of $87.3 \%$ and $91.9 \%$ for the experimetal and simulation respectivly.

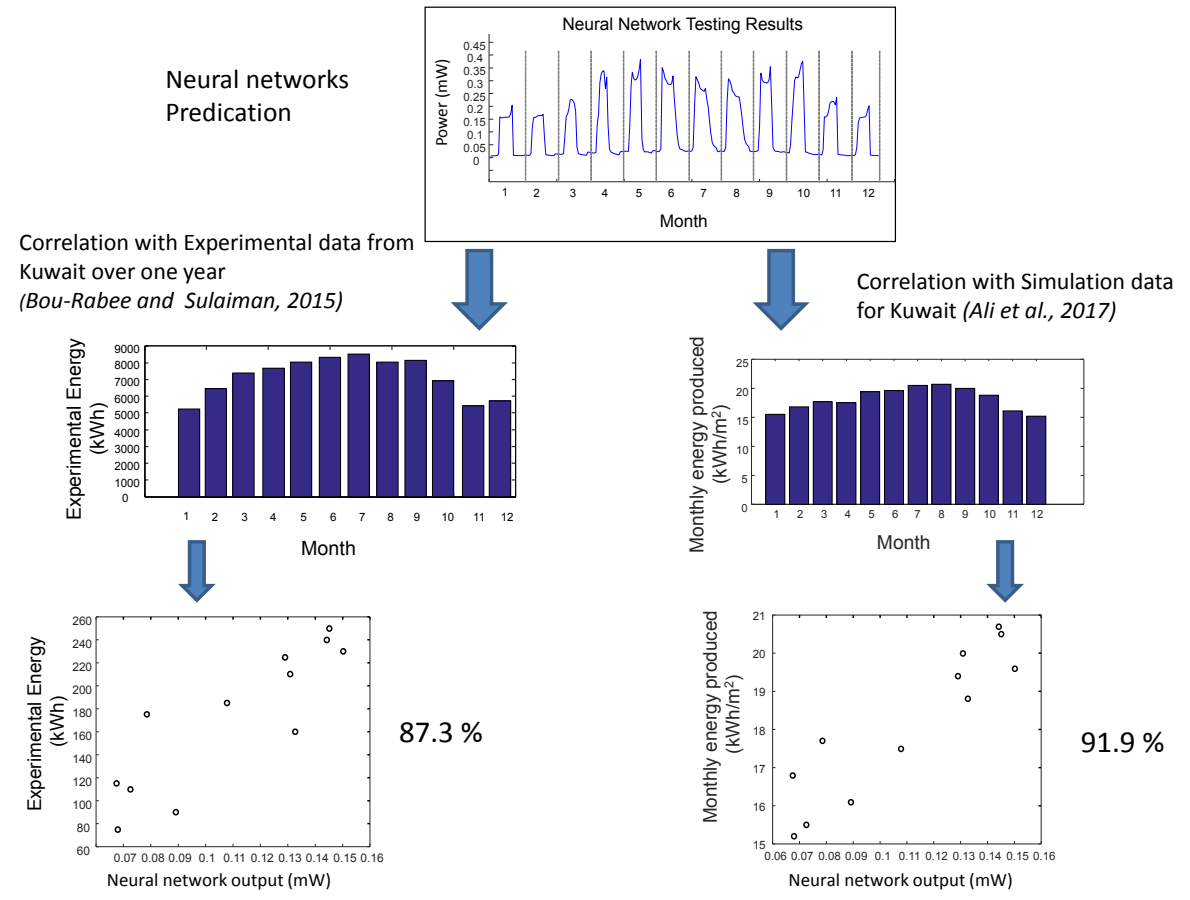

Figure 15: Comparison of the correlation between the neural network output and the experimental results and simulation with correlation between $87.3 \%$ and $91.9 \%$.

\section{Discussion}

This paper has suggested a novel approach of combining lab-testing with short-term in-situ experimental work and deep learning neural networks to predict the expected behaviour of photovoltaic technology over lengthy periods of time. The comparative photovoltaic panel 
testing for temperature and lab testing for angle has been found to provide a quick assessment of the general behaviour of the panels used in relation to their sensitivity for the two conditions (i.e. angle and temperature).

In general, in order to get reliable data performance of solar photovoltaic panels, in-situ testing will be needed to accurately quantify the actual output due to the wide variables that influence the performance. Many researchers have argued this and have attempted to experimentally examine the long term performance of photovoltaic panels. Research projects such as Bou-Rabee and Sulaiman (2015) and Zhao et al. (2019) have installed photovoltaic panels to actually measure the output over considerable times. This would require significant time in a specific location and huge investment. Others have combined experimental work with mathematical modelling of weather data to predict the short term performance (Li et al., 2019).

Researchers have also used neural networks to predict and assess the behaviour of photovoltaic solar panels. For example, Dhimish, et al., (2018) have compared between fuzzy logic and RBF ANN network for photovoltaic fault detection while Kaid, et al. (2018) have used adaptive neuro fuzzy inference approach to predict the failure diagnostic of in-situ photovoltaic cells. Deep learning has been implemented by Wu and Wang (2018) for real time energy management and control strategy of micro-grid. Simulation has also been performed (Ali et al., 2017) to evaluate the prformance. Some work has also been done on microhydro-photovoltaic-hybrid system, where for example Fenfack et al. (2009) have investigated the sizing a small hydro-photovoltaic-hybrid system for rural electrification in developing countries. Nevertheless, limited work has been done on predicting performance based on small scale photovoltaic panels for stand-alone systems.

When examining the previous research, it is found to be difficult to utilise the technology for small-scale photovoltaic products due to the market drive and the need to select the most suitable components and specifications. In this paper the authors have combined several techniques for the rapid assessment of components' suitability.

Figure 2 has presented the methodology to select the photovoltaic technology for micro-scale based performance in relation to temperature and tilt angle (Figure 5 and Figure 6). Based on that, the Amorphous type was selected. The slope angle and sand and dust accumulation was also tested (Figure 7). The yearly relative panel output for Kuwait is tested in Figures 8 and 9 with overall performance based on tilt angle is presented in Figure 10. In-situ testing in Kuwait is presented in Figure 11. Supervised neural network is used to feed the lab data, the tilt angle, the month, environmental temperature, temperature efficiency of the solar panel and solar radiation at location as described in Figure 12.

The analysis of the neural networks has presented a reasonable agreement with actual data measured which has indicated that the suggested approach can be reasonably implemented to predict long term performance from a short-term lab testing with the use of neural networks. When data is compared with simulated and real data of other research, as in Figure 15, and the results show close correlation. Based on the results of Figures 13 and 15, the suggested approach is found to be effective in predicting the general performance trends as well as the average values. 
The results indicate a strong correlation between larger scale photovoltaic solar systems and micro-scale solar energy systems, which policy makers in Kuwait, and other countries in the Gulf region, could take into consideration when considering policy decisions in relation to distributed solar energy systems. However, further research is needed to perform cost-benefit analysis (CBA) between micro-scale systems and larger scale photovoltaic systems to evaluate its effectiveness to the end user and its effect on the grid.

\section{Conclusion}

Photovoltaic technology is becoming one the most attractive technologies for installation in different locations around the world. Micro-scale standalone off-the-grid systems are becoming very common due to ease of installation and reduced investment costs. Manufacturers find it to be difficult to select the best option of micro-scale photovoltaic panels for their systems. This paper has outlined a novel approach that combines a rapid lab data testing with short-term in-situ assessment and deep learning neural networks to predict the hourly average power output for every month of the year. The results show that the power estimation error for the neural networks, when compared the estimated data with the real data, to be between $0.4 \%$ and $23 \%$. The correlation with real data could reach between $87.3 \%$ and $91.9 \%$. Hence the suggested approach has shown considerable level of success to predict the long term behaviour of micro-scale off-the grid panels using a rapid approach for locations around the world. This paper has focused on Kuwait as a case study. However, the methodology is generic and can be used in other areas and regions. Although depending on the region, other factors such as humidity, dust and local shadow could play an important role in the results. The results also indicate that the proposed approach could provide relative accurate assessment of expected power output experimentally with possibility to scaling up the technology based on the real situation in hands. The advantage of the proposed system is that a comparative energy output and performance could be obtained in a short period of time. A small scale prototypes of the urban environment could be built and hence the optimum location for the panels could be selected. The future work will focus on testing the results in different locations around the world to see the effect of the environmental conditions on the performance of the neural networks.

\section{Acknowledgment}

The authors would like to thank Nottingham Trent University and the Public Authority for Applied Education and Training in Kuwait (PAAET) for partially funding this work and Kuwait Institute of Scientific Research (KISR) for their collaboration on the experimental work in Kuwait. Also, special thanks to the technical team at NTU for supporting this experimental work. Special thanks is due to Mr. Mark Beeston for his support and to Mr. Emmanuel Fadehan for supporting the data collection on the project. 
Post-Print Version: Eisa Almeshaiei, Amin Al-Habaibeh, Bubaker Shakmak, Rapid evaluation of micro-scale photovoltaic solar energy systems using empirical methods combined with deep learning neural networks to support systems' manufacturers, Journal of Cleaner Production, 2019, 118788, ISSN 0959-6526, https://doi.org/10.1016/j.jclepro.2019.118788. (http://www.sciencedirect.com/science/article/pii/S0959652619336583)

\section{References:}

Abdelghani-Idrissi, M.A., Khalfallaoui, S., Seguin, D., Vernières-Hassimi, L., Leveneur, S., 2018. Solar Tracker for Enhancement of the Thermal Efficiency of Solar Water Heating System. Renewable Energy 119: 79-94.

Ali, A. H. H., Zeid, H. A.R., AlFadhli, H. M.G., 2017. Energy Performance, Environmental Impact, and Cost Assessments of a Photovoltaic Plant under Kuwait Climate Condition. Sustainable Energy Technologies and Assessments 22: 25-33.

Amin, I.J., Taylor, A. J., Junejo, F., Al-Habaibeh, A., Parkin, R. M., 2008. Automated People-Counting by Using Low-Resolution Infrared and Visual Cameras. Measurement: Journal of the International Measurement Confederation 41 (6): 589-99.

Asl-Soleimani, E., Farhangi, S., Zabihi, M. S., 2001. The Effect of Tilt Angle, Air Pollution on Performance of Photovoltaic Systems in Tehran. Renewable Energy 24 (3-4): 459-68.

Avila, F.B., Dong, S., Menang, K.P., Rajczak, J., Renom, M., Donat, M.G., Alexander, L. V., 2015. Systematic investigation of gridding-related scaling effects on annual statistics of daily temperature and precipitation maxima: a case study for south-east Australia. Weather Clim. Extremes 9, 6-16.

Balibar, S., 2017. Energy Transitions after COP21 and 22. Comptes Rendus Physique 18 (78): 479-87.

Bandoc, G., Prăvălie, R., 2015. Climatic water balance dynamics over the last five decades in Romania's most arid region, Dobrogea. J. Geogr. Sci. 25: 1307-1327

Bandoc, G., Prăvălie, R., Patriche, C., Degeratu, M., 2018. Spatial Assessment of Wind Power Potential at Global Scale. A Geographical Approach. Journal of Cleaner Production 200: 1065-86.

Bou-Rabee, M.A., Sulaiman, S.A., 2015. On Seasonal Variation of Solar Irradiation in Kuwait. International Journal Of Renewable Energy Research 5 (2): 2-7.

Cañete, C., Carretero, J., Sidrach-de-Cardona, M., 2014. Energy Performance of Different Photovoltaic Module Technologies under Outdoor Conditions. Energy 65: 295-302.

Davies, J.A., McKay, D.C., 1989. Evaluation of Selected Models for Estimating Solar Radiation on Horizontal Surfaces. Solar Energy 43 (3): 153-68.

Dhimish, M., Holmes, V., Mehrdadi, B., Dales, M, 2018. Comparing Mamdani Sugeno fuzzy logic and RBF ANN network for PV fault detection, Renewable Energy 117: 257274.

Díaz, A. C., 2013. Energy Life Cycle Assessment (LCA) of Silicon-Based Photovoltaic Technologies and the Influence of Where It Is Manufactured and Installed. Master of Renewable Energy and Energy Sustainability, University of Barcelona, http://diposit.ub.edu/dspace/bitstream/2445/57523/1/TFM_MERSE_AlejandroCalderon. pdf. 
Dupeyrat, P., Ménézo, C., Wirth, H., Rommel, M., 2011. Improvement of PV Module Optical Properties for PV-Thermal Hybrid Collector Application. Solar Energy Materials and Solar Cells 95 (8): 2028-36.

Elbreki, A.M., Alghoul, M. A., Al-Shamani, A.N., Ammar, A.A., Yegani, B., Aboghrara, A.M., Rusaln, M.H., Sopian, K., 2016. The Role of Climatic-Design-Operational Parameters on Combined PV/T Collector Performance: A Critical Review. Renewable and Sustainable Energy Reviews 57: 602-47.

Elibol, E., Özmen, Ö. T., Tutkun, N., Köysal, O., 2017. Outdoor Performance Analysis of Different PV Panel Types. Renewable and Sustainable Energy Reviews 67: 651-61.

Fan, Z. X., Thomas, A., 2013. Spatiotemporal variability of reference evapotranspiration and its contributing climatic factors in Yunnan Province, SW China, 1961-2004. Climatic Change, 116(2), 309-325.

Fthenakis, V.M., 2004. Life Cycle Impact Analysis of Cadmium in CdTe PV Production. Renewable and Sustainable Energy Reviews 8 (4): 303-334.

Fu, Q., Feng, S., 2014. "Responses of terrestrial aridity to global warming”, J. Geophys. Res. Atmos. 119: 7863- 7875.

Gholami, A., Khazaee, I., Eslami, S., Zandi, M., Akrami,E., 2018, Experimental investigation of dust deposition effects on photo-voltaic output performance, Solar Energy, 159: 346-352.

Gueymard, C., 1993. Critical Analysis and Performance Assessment of Clear Sky Solar Irradiance Models Using Theoretical and Measured Data. Solar Energy 51 (2): 121-38.

Guta, D. D., 2018. Determinants of Household Adoption of Solar Energy Technology in Rural Ethiopia. Journal of Cleaner Production 204: 193-204.

Hopwood, D., 2016. COP21 Gives Real Hope to Renewables. Renewable Energy Focus 17 (1): 1 .

IEA, 2018, Snapshot of Global Photovoltaic Markets, International Energy Agency, http://www.iea-pvps.org/fileadmin/dam/public/report/statistics/IEA-PVPS A Snapshot of Global PV - 1992-2017.pdf

IPCC, 2013. Climate Change 2013- The Physical Science Basis, Intergovernmental Panel on Climate Change, ISBN 978-92-9169-138-8, available on line at: https://www.ipcc.ch/site/assets/uploads/2018/03/WG1AR5 SummaryVolume FINAL.pdf

Jamil, B., Bellos, E., 2019. Development of Empirical Models for Estimation of Global Solar Radiation Exergy in India. Journal of Cleaner Production 207: 1-16.

Kaid, I.E. , Hafaifa, A., Guemana, M., Hadroug, N., Kouzou, A., Mazouz, L., 2018, Photovoltaic system failure diagnosis based on adaptive neuro fuzzy inference approach: South Algeria solar power plant, Journal of Cleaner Production 204: 169-182. 
Post-Print Version: Eisa Almeshaiei, Amin Al-Habaibeh, Bubaker Shakmak, Rapid evaluation of micro-scale photovoltaic solar energy systems using empirical methods combined with deep learning neural networks to support systems' manufacturers, Journal of Cleaner Production, 2019, 118788, ISSN 0959-6526, https://doi.org/10.1016/j.jclepro.2019.118788. (http://www.sciencedirect.com/science/article/pii/S0959652619336583)

Kaplanis, S.N., 2006. New Methodologies to Estimate the Hourly Global Solar Radiation; Comparisons with Existing Models. Renewable Energy 31 (6): 781-90.

Kenfack, J., Neirac, F.P., Tatietse, T.T., Mayer, D., Fogue, M., Lejeune, A., 2009, Microhydro-PV-hybrid system: Sizing a small hydro-PV-hybrid system for rural electrification in developing countries, Renewable Energy 34 (10): 2259-2263.

Klucher, T.M., 1979, Evaluation of models to predict insolation on tilted surfaces, Solar Energy 23 (2):111-114.

Li, D.H.W., Lou, S., 2018. Review of Solar Irradiance and Daylight Illuminance Modeling and Sky Classification. Renewable Energy 126: 445-53.

Li, L.L., Wen, S.Y., Tseng, M.L., Wang, C.S., 2019, Renewable energy prediction: A novel short-term prediction model of photovoltaic output power, Journal of Cleaner Production 228: 359-375.

Lou, S., Li, D. H.W, Lam, J.C., 2017. CIE Standard Sky Classification by Accessible Climatic Indices. Renewable Energy 113: 347-56.

Lude, S., Fluri, T.P., Alhajraf, S., Jülch, V., Kühn, P., Marful, A., Sanchez Contreras J. R., 2015. Optimization of the Technology Mix for the Shagaya 2 GW Renewable Energy Park in Kuwait. Energy Procedia 69: 1633-42.

Maghami, M. R., Hizam, H., Gomes, C., Radzi, M. A., Rezadad, M. I., Hajighorbani, S., 2016. Power Loss Due to Soiling on Solar Panel: A Review. Renewable and Sustainable Energy Reviews 59: 1307-16.

Mathworks, 2019. Levenberg-Marquardt Backpropagation. , Matlab Release R2109b,https://uk.mathworks.com/help/deeplearning/ref/trainlm.html (Accessed on 24 September 2019).

NASA, 2018. NASA Surface Meteorology and Solar Energy, https://eosweb.larc.nasa.gov/ (Accessed on 1 March 2018).

Nasir, D.S.N.M., Hughes, B. R., Calautit, J.K., 2017. Influence of Urban Form on the Performance of Road Pavement Solar Collector System: Symmetrical and Asymmetrical Heights. Energy Conversion and Management 149: 904-17.

Miao, S., Guangtao Ning, G., Gu, Y., Yan, J., Ma, B., 2018, Markov Chain model for solar farm generation and its application to generation performance evaluation, Journal of Cleaner Production 186: 905-917.

PVGIS, 2018, Photovoltaic Geographical Information System (PVGIS), European Commission., http://re.jrc.ec.europa.eu/pvgis.html/ (Accessed 1 March 2018).

Pindado, S., Cubas, J., 2017. Simple Mathematical Approach to Solar Cell/Panel Behavior Based on Datasheet Information. Renewable Energy 103: 729-38. 
Prăvălie, R., Bandoc, G., 2018. Nuclear Energy: Between Global Electricity Demand, Worldwide Decarbonisation Imperativeness, and Planetary Environmental Implications. Journal of Environmental Management 209: 81-92.

Prăvălie, R., Bandoc, G., Patriche, C., Sternberg, T., 2019a. Recent changes in global drylands: Evidences from two major aridity databases. Catena 178: 209-231

Prăvălie, R., Patriche, C., Bandoc, G., 2019b. Spatial assessment of solar energy potential at global scale. A geographical approach. Journal of Cleaner Production 209: 692-721.

Rajgor, G., 2016. Greater Acceleration of Renewables Required to Meet COP21 Goal. Renewable Energy Focus 17 (5): 175-77.

Seager, R., Ting, M.F., Held, I.M., Kushnir, Y., Lu, J., Vecchi, G., Huang, H.-P., Harnik, N., Leetmaa, A., Lau, N.-C., Li, C., Velez, J. , Naik, N., 2007. Model Projections of an Imminent Transition to a More Arid Climate in Southwestern North America. Science $316(5828): 1181-1184$.

Sharaf-Eldin, S. A., Abd-Elhady, M.S., Kandil, H. A., 2016. Feasibility of Solar Tracking Systems for PV Panels in Hot and Cold Regions. Renewable Energy 85: 228-33.

Touati, F., Massoud, A., Abu Hamad, J., Saeed, S. A., 2017. Effects of Environmental and Climatic Conditions on PV Efficiency in Qatar. Renewable Energy and Power Quality Journal 11: 262-67.

Wu, N, Wang, H, 2018, Deep learning adaptive dynamic programming for real time energy management and control strategy of micro-grid, Journal of Cleaner Production 204: $1169-1177$.

Xu, L., Stein, W., Kim, J. S., Wang, Z., 2018. Three-Dimensional Transient Numerical Model for the Thermal Performance of the Solar Receiver. Renewable Energy 120: 55066 .

Zhao, J., Ma, T., Li, Z., Song, A., 2019. Year-round performance analysis of a photovoltaic panel coupled with phase change material, Applied Energy 245: 51-64. 